\title{
Traumatic hemipelvectomy (amputae) Report of one case
}

\author{
Errol U.Hutagalung*, Qomarrudin**
}

\begin{abstract}
Abstrak
Traumatik hemipelvektomi merupakan cedera teramat berat diakibatkan oleh trauma tumpul yang hebat, sehingga seluruh tungkai teravulsi melalui sakroiliak dan simfisis pubis. Penderita yang dapat selamat dari cedera luar biasa ini hanya sedikit. Dilaporkan satu kasus traunatic hemipelvektomi yang selamat pada penderita perempuan usia 25 bulan. Kasus ini merupakan yang pertama dilaporkan dari Indonesia. (Med J Indones 2001; 10:169-73)
\end{abstract}

\begin{abstract}
Traumatic hemipelvectony (amputae) is a catastrophic injury resulting from violent shearing forces which avulsed the lower limb at the level sacroiliac joint and symphisis pubis. Patients surviving traumatic hemipelvectomy are rare. One case of a 25 months old girl surviving traumatic hemipelvectomy is presented. This is the first case reported from Indonesia. (Med J Indones 2001; 10: 169-73)
\end{abstract}

Keywords: Colostomy, skin graft, traffic accident

Traumatic hemipelvectomy (amputae) is rarely observed because very few patients have survived from this kind of devastating injury.

A review of the literature up to $1999^{1,2}$ yielded on 61 surviving cases with such an injury.

We report a 25 months old girl who survived from this massive trauma.

To our knowledge this is the first case ever reported from Indonesia.

\section{Case Report}

A 25 months old girl, who was traveling with her parents in a bus was involved in a traffic accident outside of Jakarta.

Her right lower limb was crushed at the level of her right hemipelvis, she was immediately brought to a local hospital, where she was resuscitated. Control of the bleeding and packing of the open wound was done. After her condition was stabilized, she was

\footnotetext{
* Division of Orthopaedic Surgery, Faculty of Medicine University of Indonesia/Dr. Cipto Mangunkusumo

Hospital, Jakarta, Indonesia

** Paediatric Surgeon, PELNI Hospital, Jakarta, Indonesia
}

transferred to a hospital in Jakarta. The patient arrived in Jakarta 2 days after the accident.

On admission, the patient was awake and alert. Pulse rate was 100 /minute and the respiration rate was $24 /$ minute, body temperature was $36,9^{\circ} \mathrm{C}$. Inspection of the wound revealed, that the right lower limb was absent at the level of the right hemipelvis, the open wound was covered with muscles, peritoneum was not exposed, there was laceration in the perineal area. A catheter was already inserted and drained clear urine.

A debridement and skin grafting was done to the opened wound.

A colostomy was performed. There were no postoperative complications. After 4 weeks of hospitalizations, she was discharged from the hospital. At the age of 7 years, she was healthy, the colostomy was functioning she had urinary continence, the right hemipelvis was covered with scar tissue, and there was a small area of granulation tissue.

\section{Discussion}

Traumatic hemipelvectomy is amputation of the lower limb through the sacroiliac joint and symphisis pubis. caused by an injury. 
It is caused by extremely violent blunt injury, and usually accompanied by injury to genito urinary tract and the bowel so that the patients needed a diverting cystostomy and colostomy. ${ }^{3,4,5}$

Wand, ${ }^{6}$ reported a case of traumatic hemipelvectomy without visceral injury, in his case the peritoneum was exposed but intact, there was also no injury to the urinary tract, and for these reasons no diverting colostomy and cystostomy were performed.

In our case there was no injury to visceral organ, but due to damage in the anorectal region, a diverting colostomy was performed. The genito urinary tract was also intact, a catheter was easily passed and the urine was clear.

Survival from traumatic hemipelvectomy appears to be related to the magnitude of initial blood loss and the presence of other injuries. 6,7

The retraction and spasm of the avulsed external iliac artery prevents immediate ex-sanguination and significantly reduce the volume of hemorrhage from the wound, this appeared to be the case in the survivors. ${ }^{7}$

We believed our case was saved by the above mentioned mechanism.

$79 \%$ of the cases reported involved motor vehicle accidents, with the remainder involving industrial machinery. ${ }^{5}$ In our case the patient was involved in a traffic accident while riding in a bus.

All of the survivors were healthy, young adult individuals who were able to tolerate massive hemorrhage and soft tissue destruction. ${ }^{5}$

Cho et $\mathrm{al}^{2}{ }^{2}$ reported a 28 months old boy who survived from this kind of violent injury. The age of our patient at the time of the accident was 25 months old. Review of the literature reveal that our case was the youngest ever reported.

The plane of disruption usually run through the sacroiliac joint and the symphisis pubis. In our case it ran through the sacroiliac joint and obturator foramen leaving the superior ramus of the right pubic bone and symphisis pubis intact. This kind of plane disruption was also reported by Klasen et al. ${ }^{3}$
The extra piece of pubic bone is useful in acting as a support for a prosthesis. ${ }^{3}$

According to Beal et $a l,{ }^{5}$ the mechanism of injury were all extremely violent traumatic events, that could divided into 3 kinds of mechanism.

First mechanism: The limb and pelvis were literally avulsed from the stationary victim after having become entangled in farm or industrial machinery.

Second mechanism : The victims were bicycle and motorcycle riders, the knee was caught by the car bumper or other object. The limb was initially in a slightly abducted and externally rotated position. As the victim continued to accelerate, the fixed limb was forced into extreme abduction and external rotation. As forward motion continued, the pubic symphisis separated and finally the sacroiliac joint was disrupted.

Third mechanism was a massive crush directly at the groin which disrupted the pubic symphisis, sacroiliac joint and ajacent bone, nerves, vessels and soft tissue.

In our case it was possible, that the third mechanism was the cause of the injury, in which her right limb was pinned and crushed by metal in the bus, at the level of her groin.

The most immediate concern in pre hospital management is hemostasis by local pressure, advanced shock therapy and prompt transfer to a hospital, if available to a trauma center.

In hospital procedures include immediate surgical hemostasis and debridement. ${ }^{2}$

If the pelvectomy was incomplete, than it should be completed, limb saving procedure endangers the patient's life.

Digestive, urinary diversion if necessary should be performed, debridement of the wound and if possible primary/secondary closure with skin grafting or muscle flap should be achieved to minimize the possibility of post operative infection and septic complication. ${ }^{5}$

When the limb was completely avulsed, packing and proximal ligation of the iliac vessel controlled the hemorrhage, this was the case in our patient. We received the patient with a complete hemipelvectomy and packed wound. 
The most common complications were $:^{5}$

1. Intractable pain due to phantom limb sensation.

2. Skin flap necrosis.

3. Systemic sepsis.

4. Vesico/urethro cutaneous fistula.

Beal et $\mathrm{al}^{5}$ reported that one of his 3 cases needed a vaginal reconstruction.

Our present case did not had any of the above mentioned complications, she had urinary continence, but she may need a vaginal reconstruction at a later date.

The last determinant of a successful outcome in this group of patients is the individual's ability to adapt psychologically to the injury. There were reports describing patients after surviving the injury developed protracted courses of drug dependency and severe psychological problems.

Successful management of patients with traumatic hemipelvectomy usually requires extraordinary effort and cooperation from a team consisting of the general surgeon, orthopedist, urologist, psychiatrist, physical therapist, and also dedicated nursing personnel.
Our present case was still very young, and she need further observation and necessary treatment to avoid psychological problems due to the disfigurement and disability caused by the severe traumatic injury.

\section{REFERENCES}

1. Pohlemann T, Paul C, Gansslen A, Regel G, Tscherne H. Traumatic hemipelvectomy. Experiences with 11 cases (abstract). Unfallchirurg 1996; 99 (4): 304-12.

2. Cho KJ, Kang YJ, Ahn J, Yoo TW. Traumatic hemipelvectomy before body image has developed (abstract). Yonsei Med J. 1999; 40(1): 80-3.

3. Klasen HJ, Ten Duis HJ. Traumatic hemipelvectomy. J Bone Joint Surg 1989; 71B: 291-5.

4. Moore WM, Brown JJ, Haynes JL, Viamontes L. Traumatic hemipelvectomy. J Trauma 1987; 27:570-2.

5. Beal SL, Blaisdell FW. Traumatic hemipelvectomy: a catastrophic injury. J Trauma 1989; 29: 1346-51.

6. Wand JS. Traumatic hemipelvectomy without visceral injury. J Bone Joint Surg 1990;72 B: 327-8.

7. Raftos JR, Ethell AT, Bye WD, Giles JS, Strange AC. Traumatic hemipelvectomy associated with contra-lateral hip dislocation: case report. J Trauma 1994; 36: 583-88. 


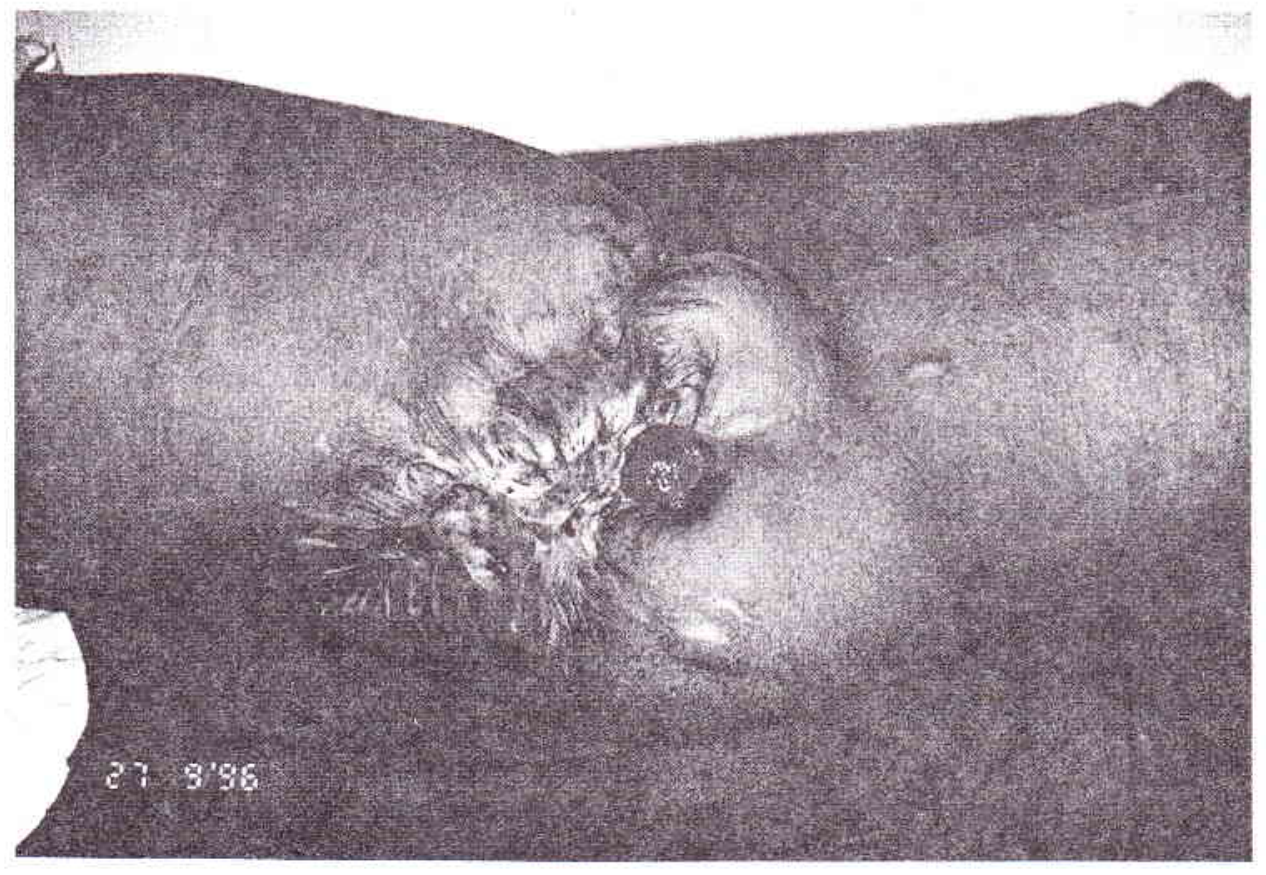

Figure 1. Side view of the patient, covered with cicatrix tissue and a small area of granulation tissue.

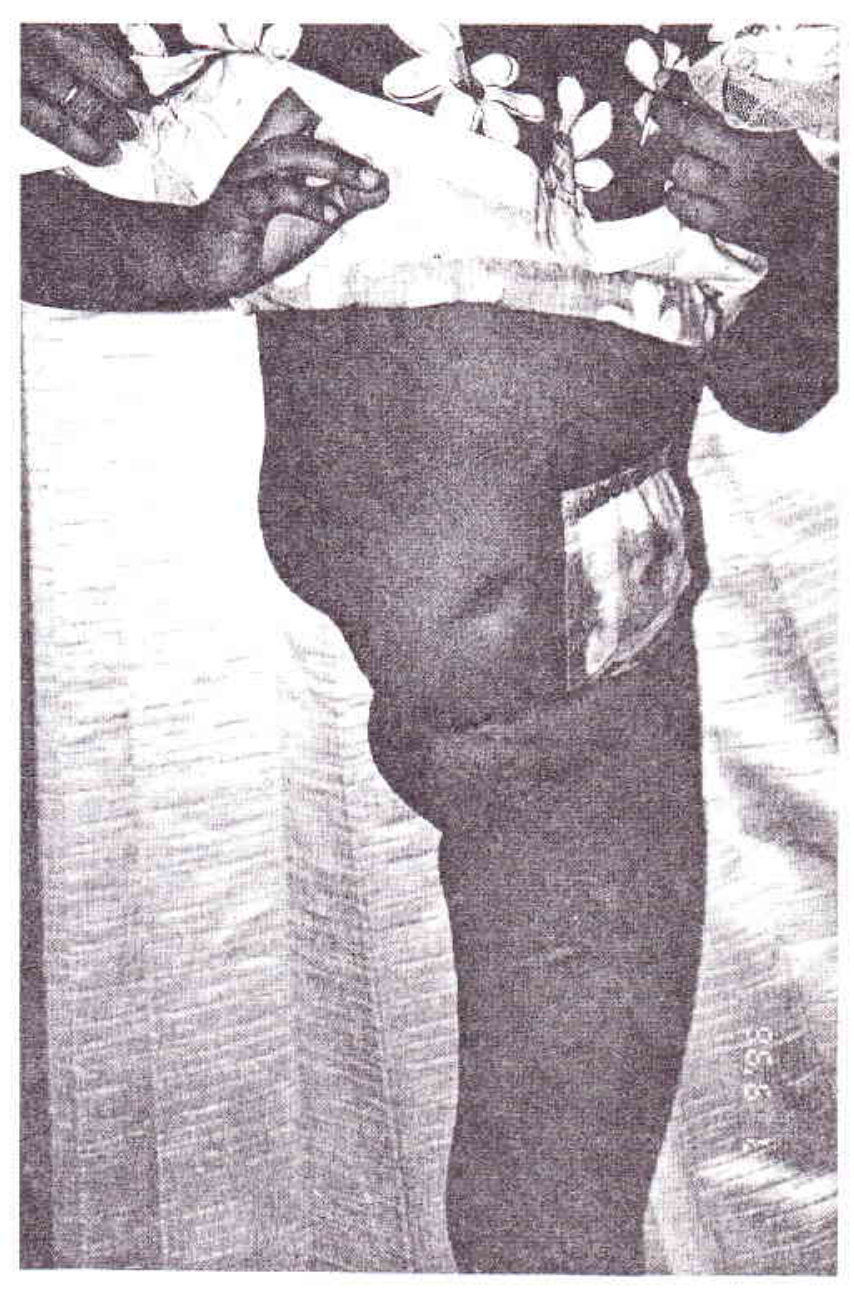

Figure 2. - Front view of the patient.

- Colosiomy on the lefi side of the abdomen. 


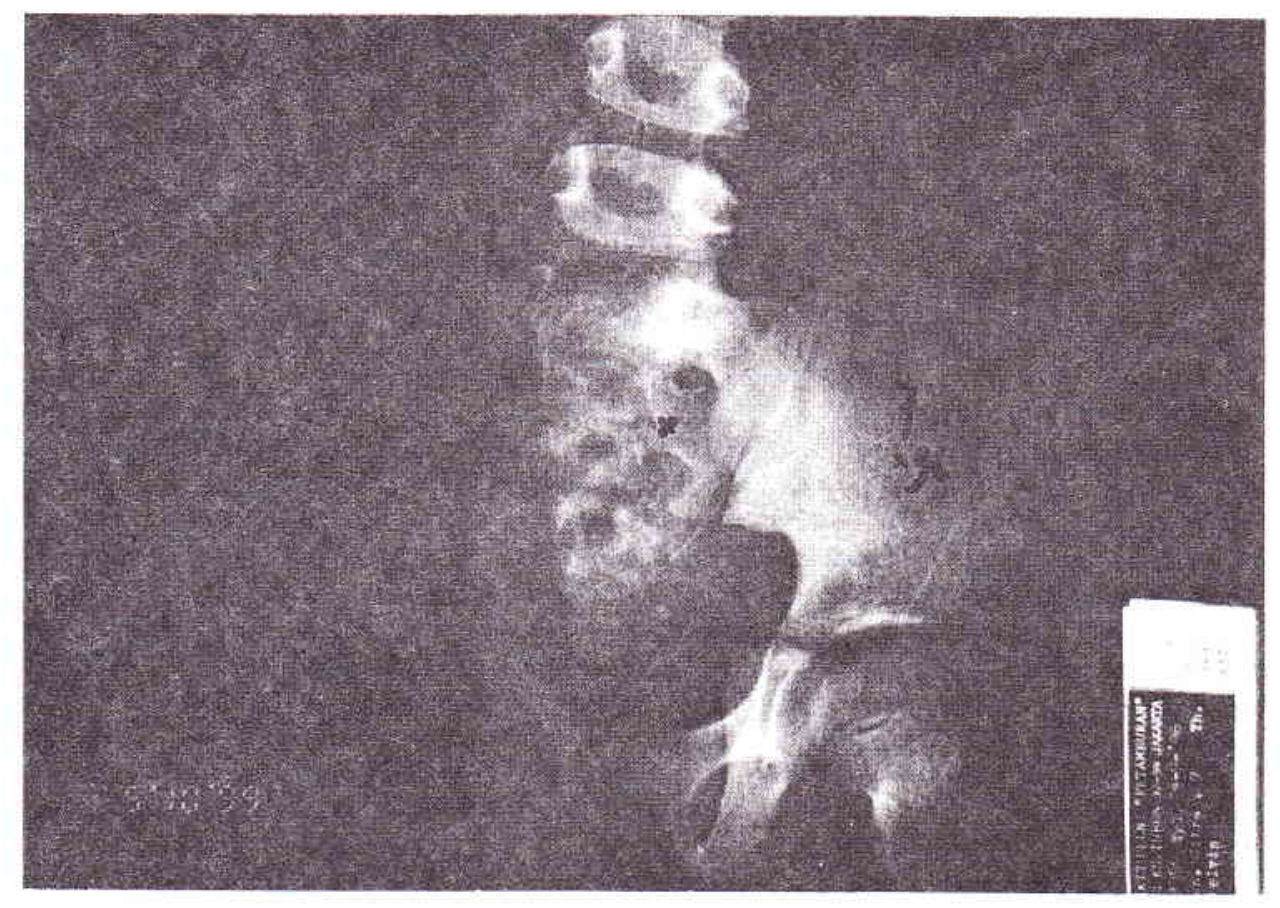

Figure 3. - X-ray of the pelvis.

- Plane of disruption went through the sacroiliac joint and obntrator foramen. 